\title{
A proteomic analysis of the functional effects of fatty acids in NIH $3 \mathrm{~T} 3$ fibroblasts
}

\author{
Juliana Magdalon ${ }^{1 *}$, Elaine Hatanaka ${ }^{1,2}$, Talita Romanatto ${ }^{1}$, Hosana G Rodrigues ${ }^{1}$, Wilson MT Kuwabara', \\ Caitriona Scaife ${ }^{1,3}$, Philip Newsholme $e^{3,4}$ and Rui Curi ${ }^{1}$
}

\begin{abstract}
Previous studies have demonstrated that long chain fatty acids influence fibroblast function at sub-lethal concentrations. This study is the first to assess the effects of oleic, linoleic or palmitic acids on protein expression of fibroblasts, as determined by standard proteomic techniques. The fatty acids were not cytotoxic at the concentration used in this work as assessed by membrane integrity, DNA fragmentation and the MTT assay but significantly increased cell proliferation. Subsequently, a proteomic analysis was performed using two dimensional difference gel electrophoresis (2D-DIGE) and MS based identification. Cells treated with $50 \mu \mathrm{M}$ oleic, linoleic or palmitic acid for $24 \mathrm{~h}$ were associated with 24, 22, 16 spots differentially expressed, respectively. Among the identified proteins, $\alpha$-enolase and far upstream element binding protein 1 (FBP-1) are of importance due to their function in fibroblast-associated diseases. However, modulation of $\alpha$-enolase and FBP-1 expression by fatty acids was not validated by the Western blot technique.
\end{abstract}

Keywords: oleic acid, linoleic acid, palmitic acid, enolase, FBP, c-myc, protein expression, proliferation

\section{Introduction}

Found in the majority of tissues of the body, fibroblasts are responsible for the synthesis and secretion of most extracellular matrix (ECM) components, such as proteoglycans, collagens, laminin and fibronectin, which bind to proteins expressed on cell surfaces thus modulating physiologic responses. Fibroblasts can also secrete proteinases, including matrix metalloproteinases and plasminogen, hence playing an important role in ECM degradation and tissue remodeling [1-3].

The dysregulation of fibroblast biology is associated with several diseases and pathological states, including deficient wound healing [4-6], pulmonary diseases [7,8], cardiovascular diseases $[9,10]$ and cancer [11]. Therefore, the discovery of new therapies modulating fibroblast biology could be a powerful target to develop treatment against such diseases. Oleic (18:1n-9), linoleic (18:2n-6) and palmitic (16:0) acids are the most abundant fatty acids in the western diets [12]. The latter is a saturated fatty acid found in palm oil, butter, milk, cheese and meats, whereas oleic acid is a monounsaturated fatty acid found in olive

\footnotetext{
* Correspondence: jumagdalon@ig.com.br

${ }^{1}$ Institute of Biomedical Sciences, University of Sao Paulo, Sao Paulo, Brazil Full list of author information is available at the end of the article
}

oil, meat, eggs and milk and linoleic acid is a polyunsaturated fatty acid found in soybean, sunflower, safflower and corn oils. The effects of prostaglandin derived from $n-3$ and $n-6$ fatty acids on specific protein expression (e.g. COX-2 and IL-6) in NIH 3T3 fibroblasts [13] and some aspects of the impact of fatty acids on process involving fibroblast function [14-16] have been reported. However, no systematic study has assessed the pleiotropic effects of fatty acids on fibroblast protein expression. Therefore, the aim of this study was to assess the effects of oleic (OLA), linoleic (LNA) or palmitic acids (PAM) on protein expression of NIH 3T3 fibroblasts, as determined by 2D-DIGE, i. e., separation of proteins by isoelectric focusing in the first dimension followed by SDS-PAGE in the second. This approach has been successful in elucidating the actions of palmitic acid on protein expression in a clonal pancreatic beta cell line, INS-1E [17].

\section{Results}

Effect of fatty acids on fibroblast membrane and DNA integrity

Fibroblast cells were incubated in the presence $50 \mu \mathrm{M}$ oleic, linoleic or palmitic acids for $24 \mathrm{~h}$. Membrane integrity and DNA fragmentation assays indicated that

\section{Biomed Central}


the fatty acids were not toxic to the cells at this concentration (Figure 1).

\section{Effect of fatty acids on relative cell number as assessed by MTT assay}

The treatment of fibroblasts with $50 \mu \mathrm{M}$ oleic, linoleic or palmitic acids increased relative cell number by 1.32 fold $(p<0.01), 1.32$-fold $(p<0.05)$ or 1.29-fold ( $p<$ $0.05)$, respectively, as assessed by MTT absorbance (Figure 2). However, the treatment with $300 \mu \mathrm{M}$ palmitic acid (known to be cytotoxic) decreased relative cell number by $50 \%$ (Figure 2).

\section{D-DIGE and MS based protein identification}

Using 2D-DIGE and Progenesis Samespots v 3.2 analyses software, a protein profile from control or fatty acid (oleic, linoleic or palmitic acids) treated fibroblasts was assessed. Comparing protein expression using Student's $t$ test, cells treated with oleic, linoleic and palmitic acid showed 24, 22, 16 spots significantly differentially expressed $(p<0.05)$, respectively, when compared to control, whereas 9, 8, 6 of them were associated with a power $>0.8$, respectively. According to spot intensity and matching from DIGE to preparative gels, 11 spots were chosen to be identified using MS (Figure 3). The majority of the spots identified contained one or two proteins when data was searched against the Swiss Prot mouse databases using Turbosequest. However, the identified proteins were not matched against their position in the gel according to their molecular weight and isoeletric point (Table 1).

\section{Protein analysis by Western blot}

Based on results obtained using 2D-DIGE and MS we selected $\alpha$-enolase and FBP-1 due to their functional importance in fibroblast-associated diseases. Therefore, western blotting was performed in order to validate our previously described results (Table 1 ). In addition, cmyc expression was assessed since FBP-1 is a known modulator (see discussion). The expression of these three proteins was not altered by treatment with fatty acids (Figure 4).

\section{Discussion}

In order to fully comprehend a biological network, the expression information from mRNA and concentration change in protein is required. The importance of proteomic analysis is emphasised when differences between the relative expression levels of mRNA and their corresponding proteins are demonstrated [18]. Several studies have analysed the effects of fatty acids on the gene expression profile of different cell and tissue types [19-24] but relatively few have studied such effects based on proteomic approaches. Our study is the first to investigate the effects of oleic (monounsaturated), linoleic (polyunsaturated) or palmitic (saturated) acids on protein expression of murine fibroblasts and related this to a functional outcome, cell proliferation.

To test the cytotoxicity or proliferative activity of the fatty acids, NIH 3T3 cells were treated with $50 \mu \mathrm{M}$ fatty acids over 24 hours and both cell viability and relative cell number were assessed using flow cytometry and MTT assay, respectively. This concentration is able to cause biological effects on other cell types [25-27] and is in the physiological range for plasma free fatty acids $[28,29]$. There was no difference between control and fatty acid treated cells based on membrane integrity and DNA fragmentation measurements, although results from the MTT assay indicated an increase in relative cell number (proliferation) in cells treated with $50 \mu \mathrm{M}$ oleic, linoleic or palmitic acids. Oleic and linoleic acids increase skeletal muscle cell proliferation, whereas a

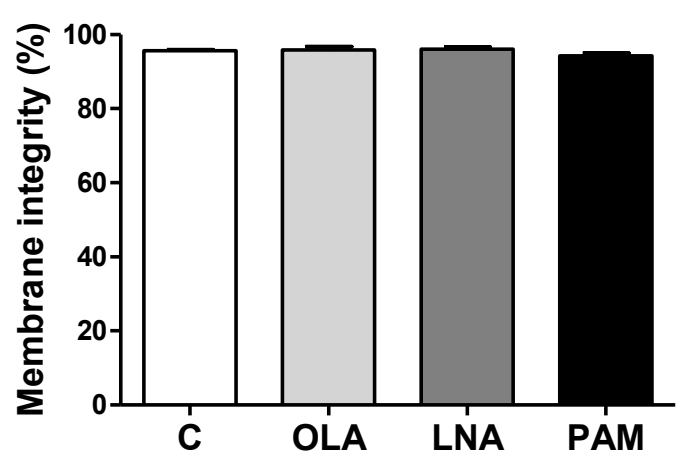

b

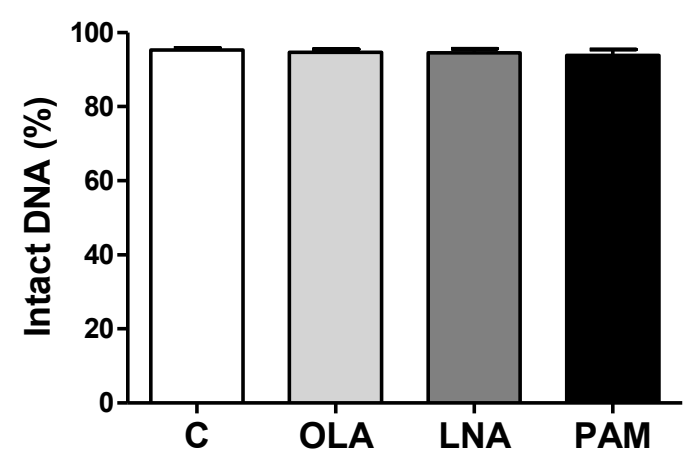

Figure 1 Analysis of membrane integrity (a) and DNA fragmentation (b): NIH 3T3 fibroblasts (10 $0^{5}$ cells) were treated with vehicle control (C), $\mathbf{5 0} \mu \mathrm{M}$ OLA, LNA or PAM for $\mathbf{2 4} \mathbf{h}$. Results are presented as mean \pm standard error of the mean (SEM) of at least 4 (membrane integrity) or 8 (intact DNA) independent samples. 


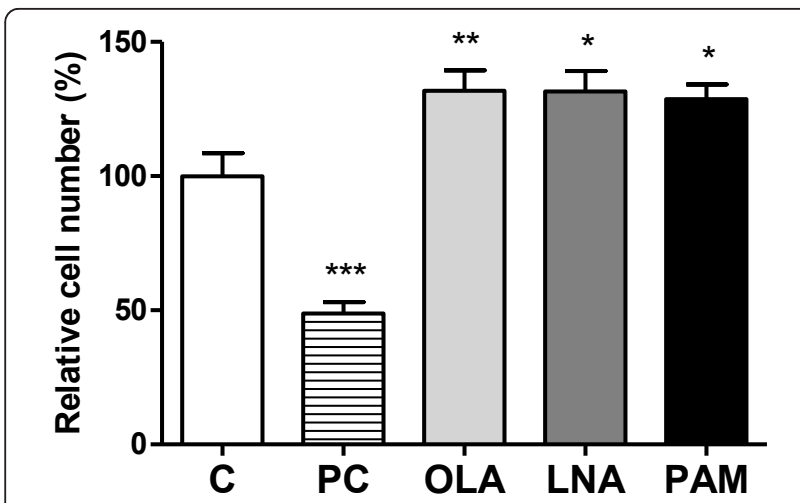

Figure 2 Analysis of relative cell number using the MTT assay: NIH 3 T3 fibroblasts $\left(6 \times 10^{3}\right.$ cells) were treated with vehicle control (C), $300 \mu \mathrm{M}$ palmitic acid (positive control - PC), $50 \mu \mathrm{M}$ OLA, LNA or PAM for $\mathbf{2 4} \mathbf{h}$. Results are presented as mean \pm (SEM) of at least 7 independent samples. ${ }^{*} p<0.05,{ }^{* *} p<0.01$ and ${ }^{* * *} p<0.001$ comparing to control (ANOVA and Dunnett post hoc test).

palmitic acid does not affect it [30]. Moreover, oleic and linoleic acids promote proliferation of epithelial cells [31].
Subsequently, a proteomic analysis was performed using 2D-DIGE. Cells treated with oleic, linoleic or palmitic acid for $24 \mathrm{~h}$ were associated with 24, 22, 16 spots differentially expressed, respectively, and 11 of them were identified by mass spectrometry using LC/MS/MS. Among the identified proteins, $\alpha$-enolase and FBP- 1 are of importance due to their function in fibroblast-associated diseases. In addition to its role in glycolysis, $\alpha$ enolase is a cell-surface plasminogen-binding site forming plasmin, which is responsible for degradating extracellular matrix compounds, such as collagen, fibrin, fibronectin and laminin [32]. Therefore, signaling initiated by plasminogen binding to the cell surface has important implications for physiological and pathological events, such as wound healing, tissue remodeling and tumor cell diffusion [33]. FBP modulates c-myc expression through binding to FUSE, that is upstream to P2 promoter [34-37]. The transcription factor c-myc plays a role in the regulation of approximately $10 \%$ of cell genes and is involved in proliferation and metabolism and hence it is considered a proto-oncogene $[38,39]$.

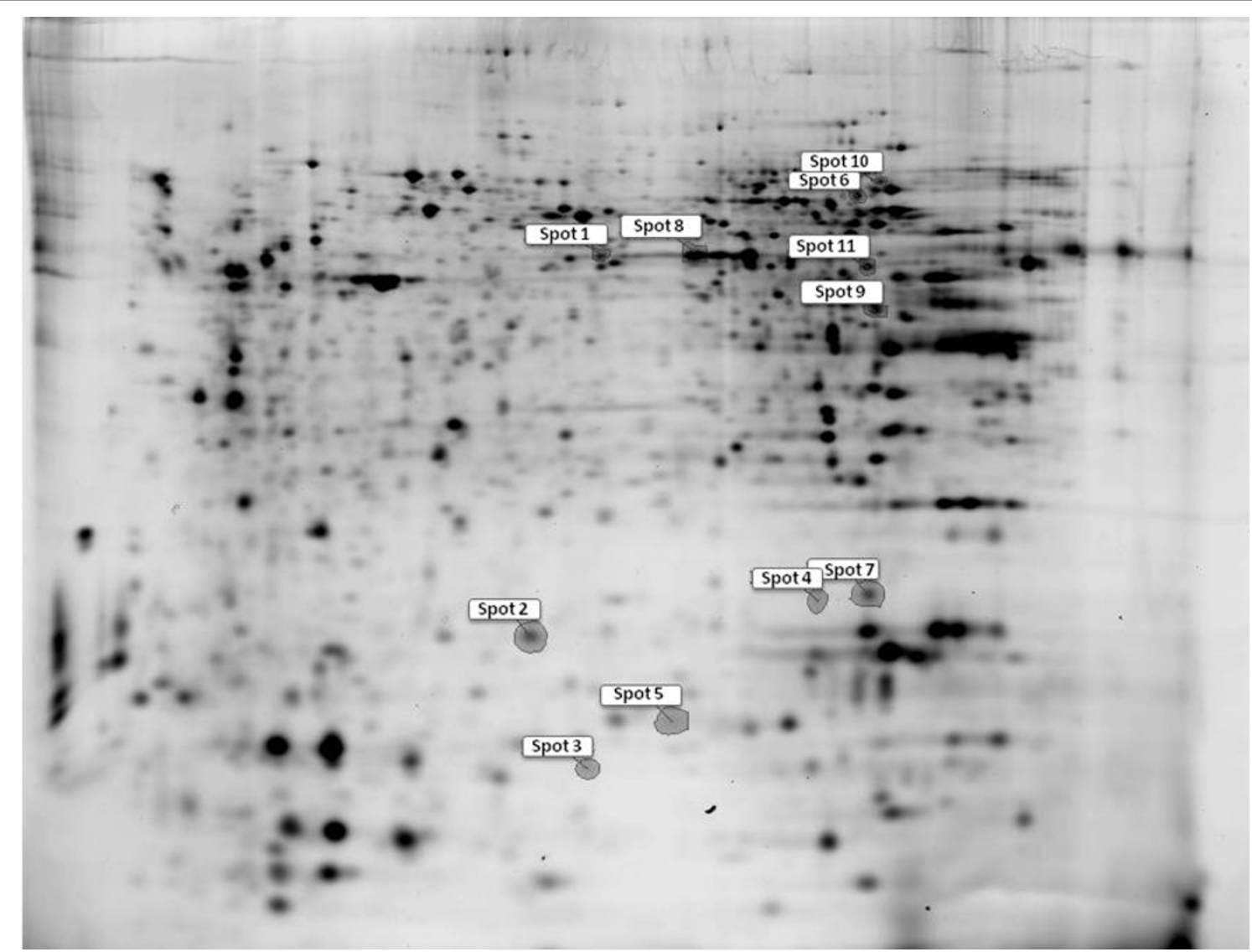

Figure 3 Analysis of protein expression using 2D-DIGE: The figure is a representative image of the gel with the excised and identified spots. 
Table 1 Proteins are described followed by accession number and the number of peptides identified using mass spectrometry of excised spots

\begin{tabular}{|c|c|c|c|c|}
\hline Spot & Identified proteins, accession number and number of peptides & Fatty acid (FA) & Control/FA ratio & Statistics \\
\hline 1 & $\begin{array}{c}\alpha \text {-enolase (P17182 - } 11 \text { peptides); } \\
\text { Mitochondrial processing peptidase subunit beta } \\
\text { (Q9CXT8 - } 3 \text { peptides) }\end{array}$ & $\begin{array}{l}\text { OLA } \\
\text { LNA }\end{array}$ & $\begin{array}{l}1.1 \\
1.1\end{array}$ & $\begin{array}{l}p<0.05 ; \text { power }>0.8 \\
p<0.05 ; \text { power }>0.8\end{array}$ \\
\hline 2 & $\begin{array}{l}265 \text { protease regulatory subunit } 8 \\
\text { (P62196- } 12 \text { peptides) }\end{array}$ & $\begin{array}{l}\text { LNA } \\
\text { OLA } \\
\text { PAM }\end{array}$ & $\begin{array}{l}1.1 \\
1.1 \\
1.1\end{array}$ & $\begin{array}{c}p<0.05 ; \text { power }>0.8 \\
p<0.05 \\
p<0.05\end{array}$ \\
\hline 3 & $\begin{array}{l}\text { Histone H\$ (P62806 - } 2 \text { peptides); } \\
\text { Histone H1.2 (P15864 - } 2 \text { peptides) }\end{array}$ & LNA & 0.9 & $p<0.05 ;$ power $>0.8$ \\
\hline 4 & $\begin{array}{l}\text { ATP synthase subunit beta (P56480 - } 4 \text { peptides); } \\
\text { Eukaryotic translational initiation factor 5A (P63242 - } 2 \text { peptides) }\end{array}$ & OLA & 1.2 & $p<0.05$; power $>0.8$ \\
\hline 5 & Nothing identified & $\begin{array}{l}\text { OLA } \\
\text { PAM }\end{array}$ & $\begin{array}{l}1.1 \\
1.1\end{array}$ & $\begin{array}{c}p<0.05 ; \text { power }>0.8 \\
p<0.05\end{array}$ \\
\hline 6 & $\begin{array}{c}\text { Heterogeneous nuclear ribonucleoprotein } L \\
\text { (Q8R081 - } 9 \text { peptides); } \\
\text { Lamin A/C (P48678 - } 7 \text { peptides) }\end{array}$ & OLA & 1.1 & $p<0.05 ;$ power $>0.8$ \\
\hline 7 & $\begin{array}{l}\text { FK506-binding protein } 4 \text { (P30416 - } 6 \text { peptides); } \\
\text { Transcription factor BTF3 (Q64152 - } 3 \text { peptides) }\end{array}$ & $\begin{array}{l}\text { PAM } \\
\text { OLA }\end{array}$ & $\begin{array}{l}1.1 \\
1.1\end{array}$ & $\begin{array}{c}p<0.05 ; \text { power }>0.8 \\
\quad p<0.05\end{array}$ \\
\hline 8 & Heterogeneous nuclear ribonucleoprotein (Q8R081 - 2 peptides) & $\begin{array}{l}\text { PAM } \\
\text { OLA }\end{array}$ & $\begin{array}{l}1.1 \\
1.1\end{array}$ & $\begin{array}{c}p<0.05 ; \text { power }>0.8 \\
\quad p<0.05\end{array}$ \\
\hline 9 & $\alpha$-enolase (P17182 - 10 peptides) & PAM & 1.1 & $p<0.05 ;$ power $>0.8$ \\
\hline 10 & $\begin{array}{l}\alpha \text {-enolase (P17182 - } 10 \text { peptides); } \\
40 \text { kDa Peptidyl prolyl cis-trans isomerase (Q9CR16 - } 4 \text { peptides) }\end{array}$ & $\begin{array}{l}\text { PAM } \\
\text { OLA }\end{array}$ & $\begin{array}{c}1.1 \\
1.05\end{array}$ & $\begin{array}{c}p<0.05 ; \text { power }>0.8 \\
\quad p<0.05\end{array}$ \\
\hline 11 & $\begin{array}{l}\alpha \text {-enolase (P17182 - } 5 \text { peptides); } \\
\text { Far upstream element-binding protein 1 (Q91WJ8 - } 4 \text { peptides) }\end{array}$ & PAM & 1.1 & $p<0.05$; power $>0.8$ \\
\hline
\end{tabular}

Where appropriate, fatty-acid treatment that significantly changed protein expression is indicated $(p<0.05)$. Abbreviations: LNA (linoleic acid), OLA (oleic acid) and PAM (palmitic acid).

We observed minor discrepancies between 2D gel and Western blot results which describe the fatty acid dependent changes in expression level of two specific proteins. However, differences in protein expression using the latter techniques have also been reported by other groups $[17,40]$. The discrepancy may be explained by the fact that the Western blot technique cannot separate different forms of proteins with specific post-translational modifications (for example, glycosylation), whereas 2D gels are able to detect differences, therefore $2 \mathrm{D}$ gel analysis is more precise. However, it should be noted that the

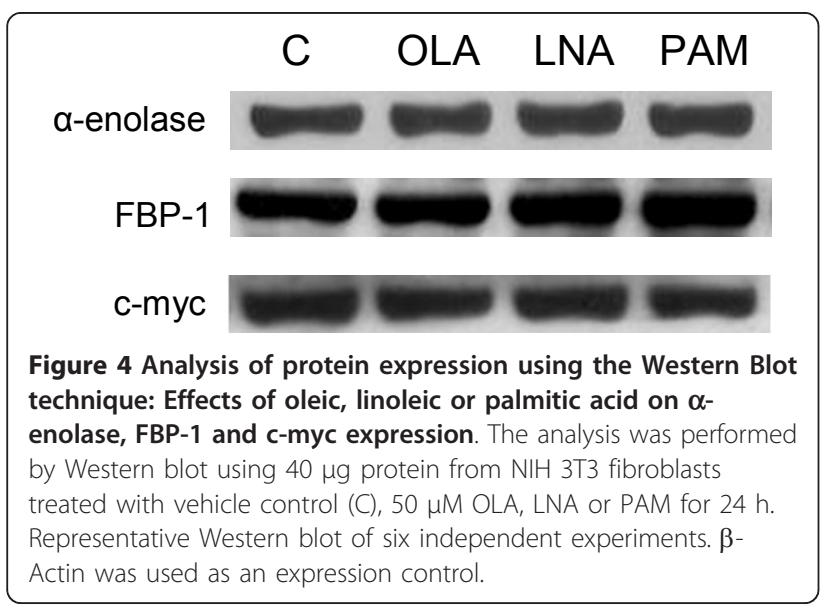

analysis from mass spectrometry in the present study identified two proteins in some spots, thus the use of Western blot was important for confirmation purposes.

In conclusion, although previous studies have reported potent effects of fatty acids on fibroblast, our results suggest that changes in protein expression using $50 \mu \mathrm{M}$ oleic, linoleic or palmitic acids for $24 \mathrm{~h}$ were relatively minor. However, it should be noted that relatively small changes in protein expression can lead to a significant change in cell proliferation.

\section{Materials and methods \\ Chemicals and reagents}

Oleic, linoleic and palmitic acids, Cell Growth Determination Kit MTT Based and Propidium Iodide were purchased from Sigma-Aldrich (St. Louis, MO, USA). Dulbecco's Modified Eagle Medium (DMEM), Penicillin Streptomycin (Pen Strep) and Fetal Bovine Serum (FBS) were purchased from Invitrogen (Carlsbad, CA, USA). Antibodies against $\alpha$-enolase and c-myc were purchased from Cell Signaling Technology (Beverly, MA, USA) and antibody against FBP-1 was from Santa Cruz Biotechnology (Santa Cruz, CA, USA).

\section{Culture conditions}

NIH 3T3 fibroblasts were cultured in DMEM medium supplemented with $10 \%$ FBS, $100 \mathrm{U} / \mathrm{mL}$ Penicilin and 
$100 \mu \mathrm{g} / \mathrm{mL}$ Streptomycin and were maintained in a humidified incubator at $37^{\circ} \mathrm{C}$ in an atmosphere of $5 \%$ $\mathrm{CO}_{2}$. After $3 \mathrm{~h}$ of incubation (for all the experiments except Western blot), the samples were washed with PBS (KCl $2.7 \mathrm{mM}, \mathrm{NaCl} 136.8 \mathrm{mM}, \mathrm{Na}_{2} \mathrm{HPO}_{4}$ anhydrous $6.4 \mathrm{mM}, \mathrm{KH}_{2} \mathrm{PO}_{4} 0.9 \mathrm{mM}-\mathrm{pH} 7.4$ ) and treated with $50 \mu \mathrm{M}$ oleic, linoleic or palmitic acids in the above medium for $24 \mathrm{~h}$. Ethanol was used as control treatment and its final concentration did not exceed $0.16 \%$.

\section{Fatty-acid cytotoxicity as determined by membrane integrity and DNA fragmentation}

In order to evaluate fatty-acid cytotoxicity, membrane integrity and DNA fragmentation were measured using flow cytometry. Fibroblasts $\left(10^{5}\right.$ cells) were incubated in 6well plates in a final volume of $1 \mathrm{~mL}$. After $24 \mathrm{~h}$ of treatment with the fatty acids, the cells were harvested using trypsin, followed by centrifugation at $500 \mathrm{~g}$. For membrane integrity assay, cells were then re-suspended in $200 \mu \mathrm{L}$ PBS and $20 \mu \mathrm{L}$ propidium iodide solution $(20 \mu \mathrm{g} / \mathrm{mL}$ in PBS) was added to each sample. For DNA fragmentation, cells were resuspended in $200 \mu \mathrm{L}$ lysis buffer $(0.1 \%$ sodium citrate and $0.1 \%$ Triton $\mathrm{X}-100$ ) with $20 \mu \mathrm{g} / \mathrm{mL}$ propidium iodide and were then incubated in dark for 30 minutes. Subsequently, cells were analysed (8000 cells/sample) in a flow cytometer (FACSCalibur, Becton Dickinson, San Juan, CA, USA) using Cell Quest software. Propidium iodide is a water-soluble fluorescent compound that cannot pass through intact plasma membrane. Therefore, when plasma membrane is disrupted, propidium iodide enters the cells and intercalates between DNA bases, which is identified by high fluorescence emission. Likewise, in the DNA fragmentation assay, propidium iodide intercalates in the exposed DNA after cell lysis and the presence of low-fluorescent fragments is indicative of DNA fragmentation. Fluorescence was measured using FL2 channel (orange-red fluorescence-585/42nm).

\section{Relative cell number as determined by the MTT assay}

MTT assay (Sigma Aldrich, St. Louis, MO, USA) is a colorimetric assay that indirectly measures cellular dehydrogenase enzyme activity, which is mainly associated with functional mitochondria. The MTT salt in the oxidized form is yellow and water-soluble and can be reduced, for example, by mitochondrial succinate dehydrogenase present in viable cells to formazan crystals. An increase in the number of viable cells results in an increase in the overall activity of mitochondrial dehydrogenases in the sample, for example, as assessed by the WST-1 assay [41]. Fibroblasts $\left(6 \times 10^{3}\right.$ cells $)$ were incubated in 96 -well plates in a final volume of $100 \mu \mathrm{L}$. For positive control (higher death rate), $300 \mu \mathrm{M}$ palmitic acid was used. After $24 \mathrm{~h}$ of treatment with the fatty acids, the supernatants were discarded and $100 \mu \mathrm{L} 0.1 \mathrm{~N} \mathrm{HCl}$ in anhydrous isopropanol was added in order to dissolve the formazan crystals. After dissolution, sample absorbance was measured in spectrophotometer (570 $\mathrm{nm}$ and $690 \mathrm{~nm}$ ) and plotted as the difference between the results found in both wavelengths, as specified by the supplier.

\section{Sample preparation for 2D-DIGE}

Cells were incubated in 100\% confluence in a final volume of $1 \mathrm{~mL}$. After $24 \mathrm{~h}$ of treatment with the fatty acids, samples were harvested. For harvesting the cells, the supernatant was removed and the cells were carefully washed four times in an isotonic sucrose solution $(0.35 \mathrm{M})$. A lysis buffer (9.5 M urea; 2\% CHAPS) was added and three wells pooled for each sample. Subsequently, the samples were sonicated and centrifuged at $500 \mathrm{~g}$ in a microcentrifuge. The supernatant was collected and the protein concentrations were determined using a modified protein assay [42]. The samples were then stored at $-80^{\circ} \mathrm{C}$.

\section{CyDye labeling}

In order to run 2D-DIGE, the samples were previous labeled with fluorescent dyes. A CyDye (Amersham, GE Healthcare) stock solution ( $1 \mathrm{mM})$ was made adding anhydrous DMF and stored at $-20^{\circ} \mathrm{C}$. The Cy3 (Amersham CyDye DIGE Fluor Cy3 minimal dye, GE Healthcare, 258008-61) and Cy5 (Amersham CyDye DIGE Fluor Cy5 minimal dye, GE Healthcare, 25-8008-62) solutions were prepared $(400 \mu \mathrm{M})$ using the CyDye stock solution and anhydrous dimethylformamide (DMF).

After thawing, each sample was adjusted to a final concentration of $5 \mu \mathrm{g} / \mu \mathrm{L}$ and $\mathrm{pH}$ between 8 and 9 . Forty microgram of protein from fifteen samples (three from each group sample: control, oleic, linoleic and palmitic) were independently labeled with $0.8 \mu \mathrm{L}$ of Cy5 solution. A pool standard was then prepared by mixing fifty-five microgram of all fifteen samples and the resulting mixture was labeled with $16.5 \mu \mathrm{L}$ of Cy3. All the samples, including the pool standard, were kept in the dark for $30 \mathrm{~min}$ and the reaction was then stopped by the addition of lysine (10 $\mathrm{mM}$ ) for $10 \mathrm{~min}$ on ice. DIGE dilution buffer (9.5 M Urea; 2\% CHAPS; $2 \%$ DTT; $1.6 \%$ Pharmalyte) was added to each sample so that the final volume was doubled.

Fifteen mixtures were prepared, each made of one sample labeled with Cy5 and the pool standard labeled with $\mathrm{Cy} 3$. These mixtures were stored at $-80^{\circ} \mathrm{C}$ for subsequent running independent $2 \mathrm{D}$ gels.

\section{D-DIGE}

Rehydration buffer (8 M Urea; 0.5\% CHAPS; 0.2\% Pharmalyte; $0.2 \%$ DTT) was added to each sample so that the final volume was $450 \mu \mathrm{L}$. Strips $(24 \mathrm{~cm}, \mathrm{pH} 3-10$, non-linear) were then rehydrated overnight with such solutions and covered with IPG Cover Fluid (Amersham, 17-1335-01) to avoid dehydration. After rehydration, the 
strips were placed in the Ettan IPGphor Manifold, covered with dry strip cover fluid. The isoeletric focusing was carried out on the IPGphor III IEF system (GE Healthcare) according to the following parameters: Step, 3500 V, 7500 vHrs; Gradient, 8000 V, 10 minutes; Step, 8000 V, 1 h; Step, 100 V, 12 h. Subsequently, the strips were equilibrated for 15 minutes in equilibration buffer (6 M Urea, $50 \mathrm{mM}$ TrisCl pH 8.8, 30\% (v/v) Glycerol, $2 \%(\mathrm{w} / \mathrm{v})$ SDS) containing $1 \%(\mathrm{w} / \mathrm{v})$ DTT and $15 \mathrm{~min}$ in equilibration buffer containing $2.5 \%(\mathrm{w} / \mathrm{v})$ iodoacetamine. The strips were then briefly washed in SDS electrophoresis buffer (25 mM Tris; $192 \mathrm{mM}$ Glycine; 0.1\% $(\mathrm{w} / \mathrm{v}) \mathrm{SDS}$ ) and placed on the top of $1 \mathrm{~mm}$ gels previously prepared (National Diagnostics ProtoGel kit, $30 \%$ acrylamide). $1 \% \mathrm{w} / \mathrm{v}$ agarose solution was poured on the top of each gel in order to seal and fix the strip on the gel. Following, second dimension separation was performed in a Protean Plus Dodeca cell (Bio-Rad, UK) with SDS electrophoresis buffer at $15^{\circ} \mathrm{C}$. The gels were run at $0.2 \mathrm{~W} /$ gel for $1 \mathrm{~h}$, followed by $1 \mathrm{~W} /$ gel overnight. Gel images were scanned with a Typhoon 9410 Variable Mode Imager (GE Healthcare) and analysed using Progenesis Samespots v 3.2. A significant difference between control and fatty-acid treated samples was set at $p<0.05$ and power $>0.8$ when analysed by Student's $t$-test.

\section{Sample preparation for mass spectrometry analysis}

Eleven protein spots, which were significantly differentially expressed between control and treated cells, were excised from preparative gels, which were silver-stained using a commercial kit (Silver Stain PlusOne; Amersham Pharmacia Biotech, Amersham, UK). The silver-stained spots of interest were manually excised, placed into $1.5 \mathrm{~mL}$ tubes and washed in $\mathrm{ddH}_{2} \mathrm{O}$ at $4^{\circ} \mathrm{C}$ overnight. The gel plugs were then destained and dehydrated, followed by their protein digestion and peptide extraction. For destaining, an equal volume of $30 \mathrm{mM}$ potassium ferricyanide and $100 \mathrm{mM}$ sodium thiosulphate was added to the gel plugs and incubated at room temperature with occasional shaking until the brown colour had disappeared. The supernatants were discarded and the plugs were washed three times with $\mathrm{ddH}_{2} \mathrm{O}$. They were then incubated in $200 \mathrm{mM} \mathrm{NH}_{4} \mathrm{HCO}_{3}$ for $20 \mathrm{~min}$ at room temperature on a thermomixer. For dehydrating, the supernatants were removed and replaced with $200 \mathrm{mM} \mathrm{NH}_{4} \mathrm{HCO}_{3}: \mathrm{ACN}:: 2: 3$ solution. The gel plugs were incubated at $37^{\circ} \mathrm{C}$ on a thermomixer for $10 \mathrm{~min}$ with gentle shaking. After briefly spinning, the supernatants were discarded and the plugs were incubated with $70 \mu \mathrm{l}$ of $50 \mathrm{mM} \mathrm{NH}_{4} \mathrm{HCO}_{3}$ at $37^{\circ} \mathrm{C}$ on a thermomixer for $10 \mathrm{~min}$ with gentle shaking. After briefly spinning, the supernatants were discarded and gel plugs were dried at $37^{\circ} \mathrm{C}$ on a Speedivac until they were white in colour. For digesting the proteins, the gel plugs were rehydrated in trypsin solution (Promega, UK, $20 \mathrm{ng} / \mu \mathrm{l}$ in $25 \mathrm{mM} \mathrm{NH}_{4} \mathrm{HCO}_{3}$, $\mathrm{pH}$ 8.4) on ice for $45 \mathrm{~min}$. The supernatants were removed and the gel plugs covered with $25 \mathrm{mM} \mathrm{NH}_{4} \mathrm{HCO}_{3}$, $\mathrm{pH}$ 8.4, and incubated at $37^{\circ} \mathrm{C}$ overnight on a thermomixer. For extracting the peptides, the supernatants were saved in separate tubes and the tryptic peptides were extracted three times with $50 \mu \mathrm{l}$ of $70 \%$ acetonitrile, $5 \%$ formic acid. Each extraction was sonicated for $5 \mathrm{~min}$ and the supernatants from the same sample were combined. These were then dried in a Speedivac and stored at $-20^{\circ} \mathrm{C}$ for subsequent protein identification using mass spectrometry.

\section{Mass spectrometry (MS) analysis}

The proteins were identified by Thermo Finnegan LTQ mass spectrometer, using LC/MS/MS. All of the data was searched against the Swiss Prot mouse databases using Turbosequest. Peptides with a probabililty of $>0.001$ were discounted.

\section{Western blot}

Fibroblasts $\left(10^{6}\right.$ cells) were incubated in $75 \mathrm{~mm}^{2}$ flasks in a final volume of $10 \mathrm{~mL}$. After $24 \mathrm{~h}$, supernatants were discarded and the cells were incubated with $50 \mu \mathrm{M}$ of oleic, linoleic or palmitic acids in DMEM (10\% FBS) in a final volume of $12 \mathrm{~mL}$ for $24 \mathrm{~h}$. Subsequently, supernatants were discarded and flasks were washed two times with ice-cold PBS. For protein extraction, $250 \mu \mathrm{L}$ extraction buffer (10 mM EDTA, $100 \mathrm{mM}$ TRIS, $10 \mathrm{mM}$ sodium pyrophosphate, $100 \mathrm{mM}$ sodium fluoride, $10 \mathrm{mM}$ sodium vanadate, $2 \mathrm{mM}$ PSMF, $3 \%$ aprotinin, $1 \%$ Triton $\mathrm{X}-100)$ was added, the cells were scraped and then harvested. After $10 \mathrm{~min}$ of shaking in $4^{\circ} \mathrm{C}$, samples were centrifuged $\left(11000 \mathrm{rpm}, 15 \mathrm{~min}, 4^{\circ} \mathrm{C}\right)$ and the proteins in the supernatants were quantified by the Bradford method. Subsequently, Laemmli sample buffer with $200 \mathrm{mM}$ dithiothreitol (DTT) was added to the samples. They were then boiled for $5 \mathrm{~min}$ and frozen at $-80^{\circ} \mathrm{C}$.

For immunoblotting, the samples were boiled for $5 \mathrm{~min}$ and $40 \mu \mathrm{g}$ of total protein was separated by SDS-PAGE, transferred to nitrocellulose membranes, and blotted with anti-enolase-1 (Cell Signaling Technology, \#3810), anti-FBP-1 (Santa Cruz Biotechnology Inc, SC-11101), anti-c-Myc (Cell Signaling Technology, \#9402) and anti$\beta$-Actin (Cell Signaling Technology, \#4967). Subsequently, the blots were incubated with HRP-conjugate antibodies for $2 \mathrm{~h}$ and bands were detected by chemiluminescence using Amersham Biosciences (RPN 2209), with following exposure of the membranes to radiographic films. $\beta$-Actin was used as an expression control.

\section{Statistical analysis}

For all the experiments except 2D-DIGE, the comparison between control and samples treated with oleic, linoleic or palmitic acids were performed using ANOVA 
and Dunnett post hoc test. For 2D-DIGE, the comparison between control and samples treated with oleic, linoleic or palmitic acids were performed using Student's $t$ test.

\section{Abbreviations}

2D-DIGE: two dimensional difference gel electrophoresis; ECM: extracellular matrix; FBP-1: far upstream element binding protein 1; FUSE: far upstream element; LNA: linoleic acid; OLA: oleic acid; PAM: palmitic acid.

\section{Acknowledgements}

We thank UCD Conway Institute for providing access to proteomic facilities during the course of this work. This study was supported by Fundação de Amparo à Pesquisa do Estado de São Paulo (FAPESP), Conselho Nacional de Desenvolvimento Científico e Tecnológico (CNPq) and Coordenação de Aperfeiçoamento de Pessoal de Nível Superior (CAPES).

\section{Author details}

Institute of Biomedical Sciences, University of Sao Paulo, Sao Paulo, Brazil. ${ }^{2}$ Institute of Physical Activity and Sport Sciences, University Cruzeiro do Sul, Sao Paulo, Brazil. ${ }^{3}$ School of Biomolecular and Biomedical Science, University College Dublin, Dublin, Ireland. ${ }^{4}$ School of Biomedical Sciences, Curtin University, Perth, Western Australia 6845, Australia.

\section{Authors' contributions}

JM conceived the study, participated in its design, acquisition of data, statistical analysis and drafted the manuscript; EH conceived the study and participated in its design; TR participated in the Western Blotting; HGR participated in the MTT assay; WMTK participated in the Western Blotting; CS participated in the 2D-DIGE and carried out mass spectrometry analysis; PN participated in the design of the study and helped to draft the manuscript; RC conceived the study, participated in its design and coordination and helped to draft the manuscript. All authors read and approved the final manuscript.

\section{Competing interests}

The authors declare that they have no competing interests.

Received: 18 October 2011 Accepted: 24 November 2011 Published: 24 November 2011

\section{References}

1. McAnulty RJ: Fibroblasts and myofibroblasts: their source, function and role in disease. Int J Biochem Cell Biol 2007, 39:666-671.

2. Birkedal-Hansen H: Proteolytic remodeling of extracellular matrix. Curr Opin Cell Biol 1995, 7:728-735

3. Mutsaers SE, Bishop JE, McGrouther G, Laurent GJ: Mechanisms of tissue repair: from wound healing to fibrosis. Int J Biochem Cell Biol 1997, 29:5-17.

4. Wang HJ, Pieper J, Schotel R, van Blitterswijk CA, Lamme EN: Stimulation of skin repair is dependent on fibroblast source and presence of extracellular matrix. Tissue Eng 2004, 10:1054-1064.

5. van der Veer WM, Bloemen MC, Ulrich MM, Molema G, van Zuijlen PP, Middelkoop E, Niessen FB: Potential cellular and molecular causes of hypertrophic scar formation. Burns 2009, 35:15-29.

6. Diegelmann RF, Evans MC: Wound healing: an overview of acute, fibrotic and delayed healing. Front Biosci 2004, 9:283-289.

7. Thannickal VJ, Toews GB, White ES, Lynch JP, Martinez FJ: Mechanisms of pulmonary fibrosis. Annu Rev Med 2004, 55:395-417.

8. Postma DS, Timens W: Remodeling in asthma and chronic obstructive pulmonary disease. Proc Am Thorac Soc 2006, 3:434-439.

9. Porter KE, Turner NA: Cardiac fibroblasts: At the heart of myocardial remodeling. Pharmacology \& Therapeutics 2009, 123:255-278.

10. Lindsey ML, Borg TK: Understanding the role of the extracellular matrix in cardiovascular development and disease: where do we go from here? Journal of Molecular and Cellular Cardiology 2010, 48:431-432.

11. Kalluri R, Zeisberg M: Fibroblasts in cancer. Nat Rev Cancer 2006, 6:392-401.
12. Nutrient Intakes from Food: Mean Amounts Consumed per Individual, by Gender and Age, What We Eat in America, NHANES 2007-2008. U.S Department of Agriculture, Agricultural Research Service; 2010.

13. Bagga D, Wang L, Farias-Eisner R, Glaspy JA, Reddy ST: Differential effects of prostaglandin derived from omega- 6 and omega-3 polyunsaturated fatty acids on COX-2 expression and IL-6 secretion. Proc Natl Acad Sci USA 2003, 100:1751-1756

14. Cardoso CRB, Souza MA, Ferro EAV, Favoreto S, Pena JDO: Influence of topical administration of $n-3$ and $n-6$ essential and $n-9$ nonessential fatty acids on the healing of cutaneous wounds. Wound Repair and Regeneration 2004, 12:235-243.

15. Menendez JA, Lupu R: Mediterranean dietary traditions for the molecular treatment of human cancer: Anti-oncogenic actions of the main olive oil's monounsaturated fatty acid oleic acid (18: 1n-9). Current Pharmaceutical Biotechnology 2006, 7:495-502.

16. Granados S, Quiles JL, Gil A, Ramirez-Tortosa AC: Dietary lipids and cancer. Nutricion Hospitalaria 2006, 21:42-52

17. Hovsepyan M, Sargsyan E, Bergsten P: Palmitate-induced changes in protein expression of insulin secreting INS-1E cells. Journal of Proteomics 2010, 73:1148-1155.

18. Dutt MJ, Lee KH: Proteomic analysis. Curr Opin Biotechnol 2000, 11:176-179.

19. Pegorier JP, Le May C, Girard J: Control of gene expression by fatty acids. J Nutr 2004, 134:2444S-2449S

20. Khodadadi I, Griffin B, Thumser A: Differential effects of long-chain fatty acids and clofibrate on gene expression profiles in cardiomyocytes. Arch Iran Med 2008, 11:42-49.

21. Lee MH, Hong I, Kim M, Lee BH, Kim JH, Kang KS, Kim HL, Yoon BI, Chung $\mathrm{H}$, Kong G, Lee MO: Gene expression profiles of murine fatty liver induced by the administration of valproic acid. Toxicol Appl Pharmacol 2007, 220:45-59.

22. Xiao JZ, Gregersen S, Pedersen SB, Kruhoffer M, Orntoft TF, Hermansen K: The effect of chronic exposure to fatty acids on gene expression profile in clonal insulin-producing cells. Diabetologia 2001, 44:A30-A30.

23. Joseph SJ, Robbins KR, Pavan E, Pratt SL, Duckett SK, Rekaya R: Effect of diet supplementation on the expression of bovine genes associated with Fatty Acid synthesis and metabolism. Bioinform Biol Insights 2010 4:19-31

24. Coyne GS, Kenny DA, Waters SM: Effect of dietary n-3 polyunsaturated fatty acid supplementation on bovine uterine endometrial and hepatic gene expression of the insulin-like growth factor system. Theriogenology 2011, 75:500-512.

25. Martins de Lima-Salgado T, Coccuzzo Sampaio S, Cury-Boaventura MF, Curi R: Modulatory effect of fatty acids on fungicidal activity, respiratory burst and TNF-alpha and IL-6 production in $\mathrm{J774}$ murine macrophages. Br J Nutr 2011, 105:1173-1179.

26. Hatanaka E, Levada-Pires AC, Pithon-Curi TC, Curi R: Systematic study on ROS production induced by oleic, linoleic, and gamma-linolenic acids in human and rat neutrophils. Free Radic Biol Med 2006, 41:1124-1132.

27. Siefken W, Hoppner H, Harris IR: Regulation of cholesterol synthesis by oleic and palmitic acid in keratinocytes. Exp Dermatol 2000, 9:138-145.

28. Zhou L, Vessby B, Nilsson A: Quantitative role of plasma free fatty acids in the supply of arachidonic acid to extrahepatic tissues in rats. J Nutr 2002, 132:2626-2631.

29. de Almeida IT, Cortez-Pinto H, Fidalgo G, Rodrigues D, Camilo ME: Plasma total and free fatty acids composition in human non-alcoholic steatohepatitis. Clin Nutr 2002, 21:219-223.

30. Tachibana H, Lee JH, Morinaga Y, Fujimura Y, Yamada K: Modulation of proliferation and differentiation of $\mathrm{C} 2 \mathrm{C} 12$ skeletal muscle cells by fatty acids. Life Sciences 2009, 84:415-420

31. Yonezawa T, Haga S, Kobayashi Y, Katoh K, Obara Y: Unsaturated fatty acids promote proliferation via ERK1/2 and Akt pathway in bovine mammary epithelial cells. Biochemical and Biophysical Research Communications 2008, 367:729-735.

32. Pancholi V: Multifunctional alpha-enolase: its role in diseases. Cell Mol Life Sci 2001, 58:902-920.

33. Plow EF, Herren T, Redlitz A, Miles LA, Hoover-Plow JL: The cell biology of the plasminogen system. FASEB J 1995, 9:939-945.

34. Duncan R, Bazar L, Michelotti G, Tomonaga T, Krutzsch H, Avigan M Levens D: A sequence-specific, single-strand binding protein activates the far upstream element of c-myc and defines a new DNA-binding motif. Genes Dev 1994, 8:465-480. 
35. He L, Liu J, Collins I, Sanford S, O'Connell B, Benham CJ, Levens D: Loss of FBP function arrests cellular proliferation and extinguishes c-myc expression. Embo Journal 2000, 19:1034-1044.

36. Liu J, He L, Collins I, Ge H, Libutti D, Li J, Egly JM, Levens D: The FBP interacting repressor targets TFIIH to inhibit activated transcription. Mol Cell 2000, 5:331-341.

37. Michelotti GA, Michelotti EF, Pullner A, Duncan RC, Eick D, Levens D: Multiple single-stranded cis elements are associated with activated chromatin of the human c-myc gene in vivo. Mol Cell Biol 1996, 16:2656-2669.

38. Levens D: Disentangling the MYC web. Proc Natl Acad Sci USA 2002, 99:5757-5759

39. Levens DL: Reconstructing MYC. Genes Dev 2003, 17:1071-1077.

40. Johnson JD, Bernal-Mizrachi E, Alejandro EU, Han Z, Kalynyak TB, Li H, Beith JL, Gross J, Warnock GL, Townsend RR, et al: Insulin protects islets from apoptosis via Pdx1 and specific changes in the human islet proteome. Proc Natl Acad Sci USA 2006, 103:19575-19580.

41. Keane DC, Takahashi HK, Dhayal S, Morgan NG, Curi R, Newsholme P: Arachidonic acid actions on functional integrity and attenuation of the negative effects of palmitic acid in a clonal pancreatic beta-cell line. Clin Sci (Lond) 2011, 120:195-206.

42. Ramagli LS, Rodriguez LV: Quantitation of Microgram Amounts of Protein in Two-Dimensional Polyacrylamide-Gel Electrophoresis Sample Buffer. Electrophoresis 1985, 6:559-563.

\section{doi:10.1186/1476-511X-10-218}

Cite this article as: Magdalon et al:: A proteomic analysis of the functional effects of fatty acids in NIH $3 \mathrm{~T} 3$ fibroblasts. Lipids in Health and Disease 2011 10:218.

\section{Submit your next manuscript to BioMed Central and take full advantage of:}

- Convenient online submission

- Thorough peer review

- No space constraints or color figure charges

- Immediate publication on acceptance

- Inclusion in PubMed, CAS, Scopus and Google Scholar

- Research which is freely available for redistribution

Submit your manuscript at www.biomedcentral.com/submit 